\title{
Knowledge and Its Subjects
}

\author{
Liubov Bronzino \\ Department of Sociology \\ Faculty of Humanities and Social Sciences \\ Peoples' Friendship University of Russia \\ Miklukho-Maklay str., 10/2, Moscow, Russia, 117198 \\ E-mail: lbronzino@gmail.com
}

\author{
Elena Kurmeleva \\ Department of Social Philosophy \\ Faculty of Humanities and Social Sciences \\ Peoples' Friendship University of Russia \\ Miklukho-Maklay str., 10/2, Moscow, Russia, 117198 \\ E-mail: kurmelena@gmail.com
}

\author{
Olga Maximova \\ Department of Foreign Languages \\ Faculty of Humanities and Social Sciences \\ Peoples' Friendship University of Russia \\ Miklukho-Maklay str., 10/2, Moscow, Russia, 117198 \\ E-mail: maximova_ob@pfur.ru
}

\begin{abstract}
This article dispels some of the most popular myths about the "knowledge society" and the delusions they create regarding intellectuals and their activities. The analysis makes use of both research (M. McLuhan, M. Foucault, U. Eco, R. Collins) and literary (M. Bradbury) sources. Ideally, the reader should be tempted to arrive at a rather positive conclusion in regards to the intrinsic ambivalence of knowledge and its live environment traditionally populated by intellectuals in our society.
\end{abstract}

Keywords-knowledge; education; knowledge society; intellectual; postmodernism; simulacrum

\section{INTRODUCTION}

Fascinated by the idea of forming a "knowledge society", contemporary intellectuals are eagerly waiting for this new state to impact them. If the hypothesis stating that we are about to enter an era of knowledge is correct, then it is inevitable that intellectuals will be transformed into experts with exclusive knowledge and special skills that will distinguish them from the masses of only being categorized as "well-informed citizens." In this sense, they will be able to evaluate incoming information, know how to navigate in its vast flow, and understand its true meaning. In essence, they will be able to transform information into knowledge: from the data and numbers, which are available to anyone who knows how to turn on the computer. Consequently, intellectuals form a socially important, practically and theoretically oriented "knowledge - power".

To a reasonable extent, this paper includes a critical consideration of the role played by intellectuals in such environment, as the goal of the study is an impartial assessment of social, cultural, scientific and educational practices that form the shape of our modern era.
II. INTELLECTUAL SHAMANISM, OR A QUESTION TO BE ASKED IN ADVANCE:WHAT Do WE MEAN BY KNOWLEDGE?

What the nature of this new knowledge is forms an important question, it is also a matter of principle, but (as is often the case with questions of principle), it is somewhat intractable, as evidenced by the persistent and yet unsuccessful attempts to resolve it. Knowledge is often assessed from the perspective of a particular methodology. However, it loses its significance beyond a certain episteme (Foucault [3]); and is often a set of characters generated by the cultural code, and true to the extent that the code itself is true (Eco [7]).

But, most often one finds that the new knowledge is defined negatively, carefully listing what it no longer is: i.e. that it is not absolute, has no fundamental novelty, and is not the result of the work of academic scientists. The main thing is that it has ceased to achieve some kind of universal notion of the "truth", which, as they say, simply doesn't exist. The latter circumstance could have created frustration in their own strength, but the intellectuals still have not abandoned the idea of their exclusive social significance. To substantiate this fact logically would not be easy in the new environment as the verification mechanism is significant only when there is at least the hypothetical possibility of relating to the truth or to what is meant by this in modern science. However, because the guidelines do not actually exist, one can say anything they want. For intellectuals, this means absolute freedom - and this also implies absolute unaccountability as well. The age-old dream has come true - you can now play the "Glass Bead Game", and sit in an ivory tower and tell others obscure, but precisely because of this, mystically appealing words. What has been formed is an interesting version of a kind of "intellectual shamanism": it is not I who mumbles unintelligible words, but it is you, the mere mortals, who are not able to understand me. So be jealous, but do not dare cross the threshold of my cell. Your job as minions is to 
provide for me financially, but I will reflect for the benefit of your spiritual progress, or so the argument goes.

Such an approach is felt even when it isn't blurted out loud (and it certainly never blurts out ordinarily). Society, for their part from time to time, may wonder about what the intellectuals still do there, but such questions typically receive a decisive rebuff. The intellectuals do not care about "material matters" or the problem of who should contain a decent state of their comfort "cells" and why. The attempt to classify them in accordance with clear criteria of practical significance is found to be annoying and rejected very strongly by the intellectuals themselves. On the grounds that only a very small professional community of scholars, the exalted "inner circle", is able to evaluate such "Ideas". Thoughts for the sake of thinking, like art for art's sake, become a slogan, justifying the status of the intellectual elite, and it is so well advanced in the way of intellectual perfection that, from the "outside" of the circle, it must be heard just wondering silently (in the worst case - just silence, at best - a quiet reverence saturated with adoration).

It seems that society accepts such claims and not without sympathy. Even in Russian public opinion surveys there is some certainty in the relative prestige that academic careers occupy in the public consciousness. Although there is no consensus on this point: " $41 \%$ of respondents believe that to be a scientist in Russia today is prestigious ... Almost the same statistical weight $-42 \%$ - has the opposite view, according to which to be a scholar now is not prestigious. This opinion is more often shared by residents of Moscow $(60 \%)$ and other major cities $(57 \%)$, people with relatively high incomes (53\%), and, most notably, those who possess higher education $(54 \%)$, and those whose relatives are of academic professions (53\%)" [4]. In a different vein, the opinion about the prestige of being an academic mostly shared by people with low income, low levels of education as well as amongst rural residents - in fact, the farther away from the intellectual, the better opinion of him. However, the belief that it is good to be a scholar, rare among scholars themselves, who often complain about the lack of understanding of their higher mission and their perceived lack of financial rewards, remains quite stable.

\section{THE SCHOLAR-INTELLECTUAL SCRUTINIZED, OR ESSENTIALS ON THE BOTTOM LINE}

The image of the scholar-intellectual rarely becomes the subject of proper academic research, and the existing thoughts on this subject cannot be called uncontroversial. On the one hand, it is obvious that in the knowledge society, their role should be exceptional - in their hands surely lie the keys to progress and innovation - the consciously created fetishes of modern society. We will not dwell on these well-known concepts, treating, if not the present, then the near future of mankind as a meritocracy - the power of people with knowledge. According to F. Webster "the world is changing due to the "experts" of all sorts". Andre Gorce, Serge Mallet, Kenneth Galbraith, Daniel Bell, "all of them, describing the role of the educated members of society, pointed out some of their differences. Some isolated their technical skills, others - cognitive ability, and others - formal education. But, in fact, one thing has always stood out: the educated elites play in society a key role [1. P. 154]".

The list of researchers involved in various aspects of this problem can continue almost indefinitely. At the same time, it is often difficult to understand how a society of knowledge really functions. One thing is clear, for intellectuals themselves the classical structure is still significant universities and laboratories must exist as well as material support for the intellectual activities, periodically declare to the world the message of the greatest discoveries made in them by intellectuals, and to disseminate this knowledge to the "unenlightened" world. In particular, this world is represented by the students who voluntarily accept this mission (originally hoping to change places with their professors someday, and, by the end of the course, are almost sure that it will not make much effort to exceed them).

Without going into the debates on the specificity of their status in contemporary society, intellectuals still have the opportunity to see themselves from the outside and get an interesting picture, drawn by very curious writers. In any case, this is exactly the first impression created by the novel of M. Bradbury, Doctor Criminale [2] (on closer examination it becomes clear that the novel is written by a university professor and what is captivating in it is not irony, but self-irony).

\section{A. The Scholar-Intellectual as A Protagonist}

At first glance, it is clear that Doctor Criminale is a prominent figure and is a natural intellectual as he is supposed to be, and he has managed to accomplish that status in all aspects. On one hand he is both an outstanding scholar and a philosopher. On the other hand, he is a well-known and respected member of society that is regarded as a recognized expert on a wide range of issues and what is now referred to as a "media persona", being familiar to the general public as one who does not read books but "knows" something about everything as they "have heard". Most significantly, Doctor Criminale acts as a carrier of that same scholarship that is so highly regarded - (or, at least, should be valued in accordance with the norms generally accepted by scholars themselves) - in a knowledge society. If we were to analyze this as a philosophical text and not a novel, it would be necessary to discuss the concept of Criminale, but the novel retains the position of being written for wider audience, or "public". It is interesting that the author doesn't actually open the philosophical ideas of the famous professor, leaving only vague hints and selected aphorisms as to what these might be from his hero, dropped in a few semi-scientific dialogues and obscure speeches given at conferences.

Such is the extent of the author's neglect of proper philosophical ideas, that it cannot be accidental; rather, it accurately conveys the nature of the functioning of knowledge in modern society. That is, where the quotations and references disguise the lack of serious intellectual content, where what is valued is the ability to "speak nicely", while the thoughts are in reality shorter than sentences. This conclusion can be made based on the actual text of the novel, which refers several times to a list of popular themes through 
which you can easily pass for a thinker (and, an extraordinary thinker at that!) who is able to provide expert advice on the most complex issues. "Zhurnalets" (in the interpretation of M. Bradbury - a kind of alter ego of an intellectual and, at the same time, his counterpart of the "post humanist" era "of chaos and videos, rock music, and Sony Walkmen"), the narrator in the novel, "thanks to the last trips... learned useful words (such as Foucault and Derrida, Horkheimer and Habermas), which can open the way to the harsh academic hearts" [2. P. 458]. As a result, he wins the right to become a conduit for ideas, which are produced for the world and stored for future generations by the academic community. He writes: "Great minds have come here for a month, or even for two. Here they created avant-garde novels, alternative poems written in a geometric verse, atonal symphony, tracts on the imminent collapse of capitalism, the end of humanism, the death of Literature and the loss of self-identity" [Ibid, p. 217].

\section{B. Knowledge and Mass Media}

The journalist-narrator in the novel is no less an important figure than the professor himself. Knowledge is distributed through the media; this channel is universal, and in an era when books are read less and less, it becomes the major one. Intellectuals, who have spent a lifetime in libraries and archives, are offended to accept the fact that the current generation demonstrates an "inherent spontaneity of reactions, we think, chew and desire hastily" [Ibid, p. 15]. This means that today, "the great Wikipedia" is able to provide anyone with answers to the greatest mysteries and most priceless ideas in a compressed and easy way to read from the monitor screen format. This knowledge is ready-to-use, instantaneous and easily digestible, and, for that reason, gets so widespread in modern society. The present knowledge society is built on the foundation of that kind of knowledge - which offended intellectuals criticize for being shallow, for its reductionism, standardization, and primitivism. It does not have the required depth, they say, and is unable to stimulate the mind to a comprehensive and forward-looking analysis; it coarsens the great ideas or "dumbs" them down. It is exactly, as shown by postmodernists, "footprints" on the surface and also completely devoid of the moral principles involved. At the same time, the problem is not in the nature of knowledge itself but in its practical relevance and applicability. Simply put, the intellectuals are unwilling to admit that modern society no longer needs the knowledge which they know and have so carefully preserved.

Has knowledge itself been transformed by the way of its own distribution, or is this situation the result of the natural processes of social development? This question remains unresolved. At the same time, the opinion about the "guilt" of the media, which certainly have become the main channel for the distribution of knowledge, surpassing the reading culture, has become almost commonplace. There are also those who go even further and declare that it is the post-modernism needs to be blamed, as it described chaos with beautiful, intelligent, but extremely immoral words, creating a philosophical justification of immorality, which has been rapaciously taken advantage of by the media.
If media is really capable to change the nature of knowledge in the course of its transmission, we must agree here with M. McLuhan. The form can influence the content. However, in this case, such transformation is mainly caused primarily by pragmatic considerations. This "High knowledge" is not in any demand and not only by the wider audience, which prefers "pulp fiction" and soap operas and has not been able to understand the value of intellectual reflection and innovation. Arguably, it is not essential to society as such. What is now needed by society can fit into the format of a text message or a Wikipedia entry. Theorists who predicted the lack of demand for manual labor, the main advantage of which was a physical force were not mistaken. However, it does not mean the need to increase the role of the intellectuals as they wish to see themselves - as the holders of exclusive abilities that exceed primitive force through the power of the mind and spirit. Society needs the notorious "middle managers" who are not as sophisticated in intellectual delights in the first place. In order to characterize them as a special category, a grid has been invented and has become a requirement standard for all resumes and recruitment agencies. The central concept is the notion of "communication skills", combined with the equally vague, in terms of skills, notion of "work on the computer". They specifically now form a space of communication on the basis of that "communicability", equipped with sophisticated technical equipment, which can be mastered even by a child who is not yet able to read.

\section{System of Education}

In this regard, it is curious to see the contradictory situation of the functioning of the system of education, especially now in Russia, which contributes to the reproduction of the "office's plankton" and is forced to admit so. Obviously, this system was created based on certain ideas about knowledge and societal needs within it, or, at least, it has evolved in this direction and consequently demands respect. For example, professors of Philosophy can teach that educating students precisely is their mission and the higher purpose of their activities. The intellectual and the university community is not too worried by other details (e.g. to consider answering the question of what happens with the great number of students after they graduate, with the somehow amusing degree of Master of Philosophy, particularly regarding employment outcomes). But with special pride this community repeats that it simply has to provide "a broad university education". (But was there an intention to teach "deep" rather than "wide"?) This may explain Russia's widespread mistrust of Western educational standards: who are these "bachelors"? They are, they think, like the Russian dropouts, students who are not going to get "real" diplomas of a highly skilled specialist. There is an opinion that if we produce such degrees then the education will be degraded, or, more realistically, we will be forced to acknowledge that there is not too high demand for "higher" in every sense of the word, in education, and is, therefore, in real knowledge, the association of which is qualified as a special privilege.

This twist may seem surprising, but the Russian distrust of postmodernism, it seems, is based on the same foundation. 
Not only that post-modernism is an absolutely western phenomenon, it also brings the theoretical basis under the dubious idea of the degradation of knowledge. To explain why postmodernism is not so transparent in a theoretical sense is a complex issue that requires a separate study in itself. However, a "practical" aspect of postmodernism is directly related to the issues we have discussed here, specifically, the functioning of knowledge and the role of intellectuals.

\section{The Truth Shalt Be Truth Even in Prose or Poetry}

Let us return to the descriptions found above in $\mathrm{M}$. Bradbury's novel, in which the author so frankly describes the life of an intellectual in the postmodern era - certainly, not in the Russian reality, but nonetheless, in the circumstances very familiar to Russian readers. It can be said that the life of Doctor Criminale represents, if not the reality, the dream of any intellectual. He allows himself to do what he wants or say when and what he wants; he writes the books if he has an "inspiration", which acts not so much as the "way to" put himself in the working state as is a kind of mystical insight that he needs to wait for without worrying about the requirements of discipline, dictated by the various commitments.

In this sense, Doctor Criminale is a recognized expert on a wide range of issues, whose opinions are interesting and valued (in both a figurative sense, and in quite a direct financial one!) by everyone. People are waiting for his statements, his name is known everywhere, they forgive him for being late for a conference where he is the "keynote speaker", as well. He is forgiven for the dubious speech, which he reads with the intonation of a holder who possesses the keys to the most profound and absolute truth. He is allowed to speak on behalf of all humanity, and it seems that this right he has earned is also due to the fact that he understands how dubious his prescribed and well-deserved role really is. Regarding the content of his own "great" ideas, Doctor Criminale does not recall them immediately, though he is able to clarify and add to them, he notes that: "I said probably about the end of homo historicus, the individual who believes in the meaning or purpose of history ...In China, some old people still believe that the history is created with rifle barrels ... But they are going soon to meet their maker. And as for the rest of us... the past bothers us, and the future, that mysterious chaos... we are doomed to live forever in the present. We know nothing, and remember nothing. And that's why we cannot distinguish right from wrong, reality from illusion. Who can lead us to a different path? Would you like a cigar?" [Ibid, p. 325]

Thus, the great professor appears to be the "normal" post-modernist who doesn't believe in transcendent great ideas, and, therefore, finds himself in a very contradictory situation when he is invited to be the conduit and mouthpiece of those same great ideas. Among the latter, it is particularly sad to observe the "death", long-proclaimed by postmodernists, of varies entities: the subject and humanism, god and morality, truth and being, etc...etc. The disappearance of the author and the end of the aesthetic in this background (when the sense of history and human life is lost) - is mere "stuff", with little significance compared with the end of the social relationships. In addition, an intellectual on the level of Professor Criminale (those that are smaller, are unlikely to fall behind, but we don't talk about them), is clearly not alien to anything human. The passage about a cigar in the above quote was not omitted, and this is deliberate because the professor seems to have found, if not the eternal value, then something that is uniquely related to the goodness.

So, what, for Bradbury, is really occupying the intellectual on the postmodernist graveyard? Of course, he is talking about something, since he is being asked to speak. He also travels to conferences and congresses, embarking on an adventure of a dubious (to put it simultaneously in postmodernist-vague and classically-correct terms) financial and erotic nature - he devotes time to his hobby - erotic photography, that in times paying more attention to morality would have been considered at least slightly immoral - and now just slightly exotic. Amongst the variety of his actions, only visiting conferences and congresses can be construed as proper intellectual activity, and only if you do not know how such conferences are performed today.

The author of the impressive in scope and content "Sociology of Philosophies" R. Collins [5], describing the emergence of intellectual networks, insists on the need of direct dialogue face-to-face, direct communication, that type of dispute, during which the truth is born. Hence, the modern analogues of Plato's Academy, which are the source of inspiration for Collins, are those conferences, symposiums, and congresses. In this regard, "conferences must be respected" - is echoed by M. Bradbury to Collins, naming like this as one of the chapters of his book. Let us say at once that the greatest impression on the reader of this chapter was not from the depth of the philosophical ideas expressed in the speeches of participants but by the description of the amazing dinner, which was more sophisticated than their performances (this can be explained by the fact that technical rationality wins again over the living work of intelligence, as members gather to listen to the pre-written and printed in the proper quantity reports). In this case, the more exciting and daunting goal of the congress, the greater the chance that he will be held, and who if not Doctor Criminale knows about it firsthand: "I hope, dear friends, that one week on Barolo will be enough to ... make literature friendly with the power, to combine the idea with the chaos, but at the same time it is a good idea to also patch up the disintegrating fabric of Europe, to calm inflamed nationalism, to avoid collision with the Islamic world and do not forget to solve the problem of the "third world". If you succeed everywhere, you can assume that the time has been spent well." [2. P. 207]

It may seem strange that in describing the vicissitudes of intellectual activity of the distinguished professor, we do not pay enough attention to his publications. Although Criminale lives in the virtual-visual era and is forced to participate in a global show and play, he somehow remains a man of written culture, he reads rather than watches TV. But the spirit of the time penetrates this "inner sanctum" of classical culture and in the creative laboratory of the philosopher which produces ideas. Secrets, which had a mystical significance as long as 
they were considered an undisclosed Great Mystery of philosophical reflection, show up before the startled eyes of the curious journalists in the unfavorable light. Public cannot always get the details or some kind of gossip about Professor's private life, but, in the end, it turns out that his great ideas could have been produced either by one of his wives or by graduate students who are ready to "cooperate". The details of which are illustrated by the following long and impressively candid conversation quoted, which embodies the answer to the simple question "What are your post-graduate duties?"

A: "Well, I give students the exams ... and grade their semester work. When the professor is away, I conduct a seminar."

\section{Q: "And how often do you conduct a seminar?"}

A: "Often, as he is often away. A professor of his level has to travel a lot, this is his fate. Meanwhile, I read the lectures instead of him, write the books"

\section{Q: "Write a book? Instead of him?"}

A: "The Professor.....is a busy man, he advises ministers, attends conferences, sits on the Executive Commissions. If he will write the books himself he would not have enough time"

Q: "So you're saying that you compose a book...and it gets signed by the professor?"

A: "He signs, if he has no serious problems with the text. If there are, I must rewrite the book again. And when the book is published, sometimes I review it in some newspaper".

Q: "Well, what an awful situation. You are straining, and he cuts the coupons?"

A: "Not so easy. One day, I will get my degree and also become a distinguished professor, get a bunch of graduate students, and they will write books instead of me."

\section{Q: "That's when you get paid back?"}

\section{A: "Sure." [Ibid, pp. 104-105]}

It is noteworthy here that everyone within the academic community knows about it, and only a journalist who doesn't know much about the mysteries of the profession inside the academia can be shocked by this status quo.

This reveals a very remarkable way of functioning, as it was termed by the previously mentioned work by R. Collins, and discusses the notion of "intellectual networks". The surprising transformation of the student to the author is hardly worth taking notice of considering the absence of the greatest ideas on the production of which the intellectual networks should be directed its effort. "Why did he say it?" "That we wondered whether we really need the great ideas?" These questions are posed by the journalist who, according to the tradition of the previous epoch, still believes that the "Great Idea" must be "extracted" from the incomprehensible speech of the professor with the help of thoughtful interpretation. But the truth is said here by a Hungarian, who has concluded that the only one Great Idea of the consumer society is "shopping": "He has been always attacking but not what we need." "You're talking about Lukacs?" "Oh, who is now interested in this Lukacs? But why did he attack the shopping! What is it in shopping that he is not pleased with?" [Ibid, p. 208]

To explain this disappointing fact of such a primitive transformation of ideas from the "great into the funny" can only be done through postmodern approach. Ideas are no longer needed, but there is a need to hide this fact from the general public so as the public do not think that those intellectuals who they hoped would be able to provide the meaning (no matter of what - the meaning of life, history, people, art ...), only pretend that they work very hard in this direction. We can make a seditious assumption here that the postmodernists are not liked because they leaked out this hidden information, openly called this fraudulent activity a simulation and a game, and even wrote a large number of works resistant to almost any interpretation and translation into plain language. Arguably, such tractates justify their profound lack of meaning in everything, including the tractates themselves and their associated translations. According to the author, the list of what cannot be simulated is disappointingly brief: a cigar, a good dinner and erotic photography. All of the above, incidentally, can be regarded as different aspects of shopping - that is why shopping is a "Great Idea" and is in contrast to the idea of salvation, for instance the salvation of Europe. In addition, the number of conferences on the theme of salvation has no effect on Europe itself, but every time that same academic meeting demonstrates the delights of shopping - the great quality of copiers and a good meal. And an intellectual contributes to just the simulation of order in the chaos of reality and does not pretend to make a fairytale come true. This is another reason for which is because he is not sure whether the happy ending is planned in this fairy tale.

\section{CONCLUSION}

The views expressed here may seem irrelevant to reality. In any case, regarding Russian reality, a Russian intellectual still habitually wanders in search of a "special way", based on a shaky idea of the "mysterious Russian soul". Since the process of this search has been longstanding, there are the reasons to believe that the achieved result is not included in the plans of those who are looking for this. At the same time, what often gets ignored is that Russian reality also has a virtual counterpart - the Internet - and the new generation has for a long time believed more profoundly in this reality than in the reality of a book which was created by the intellectuals. Therefore, one might refer to this as a virtual reality. Firstly, it is initially and principally a simulation, and, secondly, this reality creates simulations of simulacra, which builds extra floors to the phantasmagoric image of Baudrillard's building.

The Russian Internet in this sense is a storehouse of examples, the strange nature of which is so obvious that it could serve to those who seek out the specifics of the Russian soul. In this virtual reality lives Doctor Criminale, illustrating the fate of the intellectual and his creations; it's 
the ideas! The Ideas cannot be found while searching on the Internet, which in itself is interesting. A novel, which by the process of being written has now become free from the author's control, has firstly become the subject of academic research as an example of an artistic expression of a simulacrum; secondly, it has become a fashionable item which you need to know in order to pass for an intellectual in the "glamorous" dimension of this world (the latter area is not invented by intellectuals, and therefore is not known in academia, but exists fine just as it is). How someone can use the novel in this sense is described in a remarkable "Dictionary of a Knowledgeable Person", published by the male web journal "Time of Men" [6]. In the article "Literature" placed next to the "Whiskey" portion of the webpage a modern, "knowledgeable" and fashionable man recommends readers know conversational phrases like "Yes, the old man Bradbury hit postmodernists where it hurt!", without the assumption that readers should actually read the novel themselves. Therefore, after reading the novel this sentence should be pronounced differently: "Postmodernists have struck back again, and this time with the words of old Bradbury!"

\section{REFERENCES}

[1] F. Webster, Theories of the Information Society, 4th edition 2014.

[2] M. Bradbury, Professor Kriminale. Moscow, 2000 (Russian edition).

[3] M. Foucault, Euvres I. II. Gallimard, 2015.

[4] On science and scientists. FOM. Data base. (2008). [Online] Available: <http://bd.fom.ru/report/cat/cult/sci_sci/d082324> (Date accessed 1.3.2016).

[5] R. Collins, The Sociology of Philosophies: A Global Theory of Intellectual Change, Harvard University Press, 2000.

[6] Time of Men, Male Web Journal, [Online] Available: http://www.mentime.ru/?id=168 (Date accessed 5.3.2016).

[7] U. Eco, De l'arbre au labyrinthe. Études historiques sur le signe et l'interprétation, essais traduits de l'italien par Hélène Sauvage, Paris, Grasset, 2010. 